Article

\title{
The Role of L2 and Cultural Mediation in the Inclusion of Immigrant Students in Italian Schools
}

\author{
Tommasa Agnese Chiofalo ${ }^{1}$, María del Mar Fernández-Martínez ${ }^{2, *}$, Antonio Luque-de la Rosa ${ }^{3}$ \\ and José Juan Carrión-Martínez ${ }^{3}$ \\ 1 Istituto Comprensivo Vittorino da Feltre, 95128 Catania, Italy; inachiofalo@gmail.com \\ 2 Departamento Sociología, Trabajo Social y Salud Pública, Universidad de Huelva, 21007 Huelva, Spain \\ 3 Departamento de Educación, Universidad de Almería, 04120 Almería, Spain; aluque@ual.es (A.L.-d.1.R.); \\ jcarrion@ual.es (J.J.C.-M.) \\ * Correspondence: mar.fernandez@dstso.uhu.es
}

Received: 4 October 2019; Accepted: 26 November 2019; Published: 28 November 2019

check for

\begin{abstract}
Background: The purpose of this research is to analyze the perception of teachers and their thinking about two specific and functional issues which are often deemed to be controversial, that is, the acquisition, by recently arrived migrant students of the host language and the role that the professional services of a cultural mediator may have in said school context. The methodology used has been a case study by means of the technique of in-depth interview. To this end, twelve teachers from an Italian comprehensive school in the region of Sicily who for several years have been immersed in the relatively abrupt arrival of immigrant students have been interviewed. Results: There is evidence of some teachers adopting the position from a classic epistemological approach in the field of interculturality. For example, while the attitude and involvement of teachers seems to be consolidated, the teachers think that a key element of real inclusion should include practical measures such as early immersion in the host language, in this case Italian, and that considerable and external professional efforts are necessary, particularly from cultural mediators, which could make the inclusive project more viable.
\end{abstract}

Keywords: immigrant student; host language (L2); intercultural mediator

\section{Introduction}

Italian schools have been deeply involved in the reception process that in recent years has brought tens of thousands of immigrants from all over the world to Italy and the rest of Europe in search of a better life. This includes newly arrived immigrants who need to learn the language and enter the school system, or a second generation of foreign teenagers, who may have even been born in Italy and who need to negotiate the difficult balance between the culture of their parents and the culture in which they live [1-3]. The educational system, sensitive to the presence of foreign students has given rise to an inclusive model where inclusion signifies a space where an individual can have their needs met through interaction, dialogue, and social participation [4,5]. Although it is true that this is a vision of institutional policy, it is one that is not always shared by teachers who demand greater specific training and institutional involvement [6].

The presence of foreigners is a phenomenon that involves all areas and all schools. Consequently, more and more teachers face the problem of having foreign students in their classes, perhaps with very different nationalities, cultures, and languages. This is a phenomenon which is expected to continue to increase in the coming years. According to the regulatory framework which has been in force in Italy for many years (there is evidence of regulation in place since 1990) [7,8], schools should play a mediating role between the different cultures of the students present in the educational system. 
Consequently, schools are sensitive to the incorporation of foreign students, and at least theoretically, maintain a favorable institutional treatment. Despite the existence of certain recent social attitudes, it is acknowledged that foreign children arriving as a result of migratory movements, whether they be uncontrolled or not, possess the same rights and duties to an education as any native student. In addition, Italian schools, at least formally, are committed to a formative response in accordance with said social scenario [9].

But is there an effective exchange between cultures? A new phenomenon, globalization, carries risks and new achievements for this exchange. While we are currently witnessing a level of physical contact between peoples and cultures which has never been seen, this dialogic context is not always easy [10]. The increasingly visible presence of immigrants in Italian cities determines the need to confront different languages, religions, and cultures on a daily basis [11].

Although in this instance, the main focus of our research is the functional issues related to school processes, such as the role of the host language as the L2 of foreign students or the professional interrelations between cultural mediators and the school, we want to position ourselves on the issue of intercultural education, understanding it as a long-awaited project of interactive and collaborative coexistence between people from different cultures destined to share social, vital, and institutional spaces $[12,13]$. Intercultural education is not a mere addition to mainstream schooling but rather, represents the norm in education in multicultural and postmodern societies. It promises to be the most advanced response to social changes at a national, European, and global level with the consequent demand for education and training of each individual and the community being one of the most vital elements in an inclusive educational project [14]. From our point of view, we can separate intercultural education from the idea of multiculturalism which is understood to be the coexistence of several different cultures, that do not necessarily engage with each other [15]. We cannot, however, ignore that the definition of these differentiated concepts is not always universal, with some conceptualizations reconciling both terms and bringing cohesion to it $[16,17]$. However the term is understood, intercultural education should not be considered as a simple set of strategies of how to teach, but rather as a way to educate with respect and with equal opportunities for all students [18].

Interculturality is neither something that appears in society nor does it exist in schools or school textbooks. Rather, interculturality is an event which comes to be in the subject's cognitive system and cognitive experience when a synthetic reinterpretation experience of various cultures is carried out. Interculturality as an experience occurs when someone perceives a narration in the thoughts of the other culture that diverges from their own that they can accept. Intercultural education is not only knowing others in person, but rather it is vital to become accustomed to the views of other cultures in the present reality being studied. Therefore, it is about becoming competent in searching points of view which are different from ours. This implies the search for materials and tools that specifically allow us to live experiences and decentralized narrative exercises, that is, how others see us, when the "others" are ourselves $[19,20]$.

\section{The Role of Schools in a Multicultural Society}

Italy, like other European countries, has undergone a transformation over the last few years, experiencing a radical change in what has always been the essence of its territorial nature. This sudden transformation has resulted in the country being consumed by a feeling of ambivalence: on the one hand, the desire to receive immigrants, whilst on the other, the fear that the presence of these people may jeopardize the security of the country itself, exposing it to the risks of violent behavior by those who have illegally entered Italian territory [21].

Whatever the attitude adopted by the Italians toward the phenomenon of migration in which the country has become immersed, this phenomenon cannot be underestimated, much less ignored. With the presence of immigrants, Italian society has also undergone a change in its appearance, assuming the increasingly marked characteristics of a new and different society, a multiethnic society, in which different ethnic groups and different cultural tensions coexist [22]. 
At the same time, the phenomenon, in addition to being social, is also educational, as schools are a reflection of a society and, therefore, the transformation experienced by civil society is also reflected in schools. Thus, just as society is called upon to begin a process of integration in order to favor the incorporation of those who have arrived in the country in search of employment or to create a more peaceful life, the same task is entrusted to schools, which then must be able to favor the inclusion of foreign students, in all its forms [23].

\subsection{Multilingualism: The Need for the Host Language}

Educational institutions, both in Italy and in all other countries around the world, have always represented spaces in which cultural and social diasporas find a way to be mediated. With regards to linguistics, we have the precedent of the Maalouf Report, written by a group of experts on behalf of the European Commission and the Commissioner for Multilingualism, headed by the Franco-Lebanese writer Amin Maalouf. This report [24] points out that multilingualism acts to improve dialogue and intercultural understanding of European citizens [25]. The study was intended to show that national school systems could guarantee both a general education and the possibility for students to learn one of the most commonly used languages of the European Community, namely English, French, or German, or, indeed, any one of the other languages of the EU. By means of this education, all students can base their lives on values of democracy and equality and have access to a quality education that allows them to easily integrate into an increasingly multicultural Europe. However, the report has become relatively obsolete, surpassed by the reality that for some, the L2 is no longer English or French, which on many occasions the immigrants already know when they arrive in the host country. Rather, it is the experiential, educational, and teaching issues, a result of the acute migration flows, that makes the L2 the national language of the host country, this is in addition to added complications when there are several co-official regional languages.

In recent years, the education system has witnessed an increase in the number of immigrant students in European classrooms, especially in countries such as Spain and Italy. The difficulties that this phenomenon has created in the educational field, especially with regard to linguistic issues, are obvious and understandable and they have generated different realizations. The first of these is the fact that today's society is experiencing many changes as a consequence of globalization processes that have resulted in the creation of interwoven societies and cultural diversity. The second consists of the emergence of a true democratic pluralism, which points to a shared culture, as well as growing interaction between different cultures [26].

Given this scenario, there is an emerging need for schools to prepare and train all young people to learn to live in mixed and heterogeneous societies, to overcome certain theoretical stigmas and to facilitate a functional inclusion of new citizens [27-29]. Therefore, educational action is not directed at ethnic or cultural minorities, but to all and for all, recognizing cultural relativity but not promoting it [30]. An issue that is always present in the debate is how L2, understood to be the language of the host country, should be treated. In this respect there is evidence that immigrant students have positive attitudes toward L2, that is, the host language [31,32], although others have found that they have a low level of linguistic proficiency, emphasizing the relationship between language proficiency and the factors that facilitate and disrupt their socialization [33]. It is important that inclusive schools allow students to use language in general, and above all, teach literacy in the host language (L2). This can act as a positive agent for a more plural and integrated construction of students' identities. The school must take care to offer an inclusive curriculum as an alternative to a more exclusive curriculum built on the preconception of the socioeconomic and linguistic deficit of immigrant students [34].

\subsection{Intercultural Mediation}

Educational institutions can become places of exchange and dialogue only if teachers, educators, and all school operators are able to implement an interdisciplinary collaboration that combines different knowledge areas and other historical, linguistic, psychological, sociological, and anthropological 
aspects [35,36]. Often, intercultural education becomes a practice only in those classes in which immigrant students are present, transforming intercultural education into a mere emergency instrument that is applied only when necessary. In contrast, intercultural pedagogy must assume the character of cultural mediation that favors dialogue and continuous exchange between different languages and cultures [22].

There are several studies and works of revision or synthesis [37] that address the teaching function in the context of vertiginous intercultural social change [38-41]. Hence, one of our main interests in this work focuses on the emerging figure of the intercultural mediator as the interpreter between different actors in the community, an interpreter that facilitates relations between the different segments of the educational community and promotes reciprocal understanding [42]. We consider intercultural mediation from a professional and institutionalized perspective as a communication role that implies leadership, empathy, and the ability to interact with the different institutional levels, overcoming the restriction of intercultural mediation as an agent aimed at aiding foreign students and projecting them as an agent for understanding cultural diversity, becoming, in the end, a part of the microsystem of schools [43-45].

In the application of intercultural practice, the intercultural mediator is one of the possible means of contact between cultures, as well as a way to prevent and resolve conflicts. It is, therefore, a form of social intervention that can (and should) be practiced in school education, among other fields, since in most societies the process of receiving immigrants is not easy, and therefore requires constant mediating actions [46]. Intercultural mediation can play a fundamental role as it appears to be one of the principal functions of the educational relationship. In addition, it can promote intercultural dialogue in schools and be the basis of a positive relationship between teachers and native peers. In our case, lack of knowledge of a language and its implicit culture can make the construction of intercultural dialogue more complex, making the role of interpreter and promoter one of the most important in cultural relationships [47]. It is very important to pay attention to the training and education of this professional figure [48] who interacts with all other roles, including teachers, social educators, and/or social workers.

Given the previously mentioned context, our research questions are as follows:

- What do teachers perceive is the impact on the school of the sudden presence of foreign students who do not know Italian?

- What do they think of and what is their assessment of the professional services of an intercultural mediator in the internal educational processes of schools?

\section{Materials and Methods}

This paper is generated in the methodological context of a case study [49]. It addresses a wide range of issues related to the process of immersion in an Italian comprehensive school with classes ranging from kindergarten to high school. It is focused on teachers expressing their perceptions and opinions on the issue of the teaching the L2, which in this case study is Italian, the host language for these foreign students, as well as their attitude toward the involvement of intercultural mediators in the complex process of integration in schools. The choice of the case study arises from a research project that aims to analyze new developments in schools, that is, the increased presence of foreign students in the classroom.

\subsection{Objectives}

- Analyze the perceptions of teachers about the impact the presence of foreign students who do not know the Italian language may have on the school.

- Given the presence of these foreign students, understand how teachers perceive the role of intercultural mediators in schools. 


\subsection{Context and Participants}

The context of the investigation has been an 'Istituto Comprensivo' in the municipality of Partanna, in the province of Trapani (Sicily). The choice of this educational institution is due to the fact that it is involved in the reception of young and recently arrived immigrants. It is a school with a population close to 1000 students comprising infant, primary, and secondary grades. At the time of this study, there were 32 foreign students of diverse origins enrolled in the school.

The school has developed an L2 literacy project aimed at foreign students with the aim of teaching Italian as a second language (L2) and, if necessary, commence a bona fide literacy course. This course is imparted to every foreign student enrolled in the school who does not know Italian. Its main aim is to initiate them in the reading and writing of the Italian language. The term L2 refers to the non-native language, that is, the host language spoken in the context in which it is used and in which it represents the native language, that is to say, the objective is to teach Italian as a second language. The main objective of the project is to provide students with the linguistic tools necessary to address the school experience in a positive and meaningful way, guaranteeing the possibility of a smooth approach to learning various and other disciplines.

An initial 15 informants were selected, although only 12 proved to be of relevance to the objectives of our research based on certain criteria [50-52]. The basic criterion included the presence of foreign students in the teachers' classes, the enrolment of students between six and ten years of age (the average age of enrolment of foreign students in the school). In addition to the abovementioned criteria, other considerations of a more practical nature had to be taken into account, such as the availability and willingness of teachers to participate in interviews, the possibility of easily accessing the context under study, a good relationship with the interviewees, and the possibility of being able to contact informants after the interview if deemed appropriate [53]. With regards to gender, the strong feminization of the teaching profession is evidenced by the presence of a solitary male teacher among the twelve informants (Table 1) [54].

Table 1. Participants.

\begin{tabular}{cc}
\hline Teacher & Gender \\
\hline IDOC1prim & $\mathrm{F}$ \\
IDOC2prim & $\mathrm{F}$ \\
IDOC3prim & $\mathrm{F}$ \\
IDOC4prim & $\mathrm{F}$ \\
IDOC5prim & $\mathrm{F}$ \\
IDOC6prim & $\mathrm{F}$ \\
IDOC7prim & $\mathrm{F}$ \\
IDOC8prim & $\mathrm{M}$ \\
IDOC9prim & $\mathrm{F}$ \\
IDOC10prim & $\mathrm{F}$ \\
IDOC11prim & $\mathrm{F}$ \\
IDOC12prim & $\mathrm{F}$ \\
\hline
\end{tabular}

\subsection{Data Collection Techniques and Data Collection Process}

The methodology of in-depth open interviews has been used [55]. The interviews were conducted with the aforementioned 12 participant teachers. Individual interviews were conducted with each teacher, always within the school, respecting the anonymity and free will of each participant.

An initial contact was established with the principal wherein the type of work and the objectives of the research were explained, gaining permission to interview teachers who had foreign students in their classes. We began the study of the phenomenon after a brief period of immersion in the field of a week, by 'wandering around' [56], in order to better understand what we were going to hear, to better represent reality, and to later conduct the interviews. 
With regards to process of conducting the interviews, an initial spontaneous exploratory contact was established in order to generate a climate of positive confidence and facilitate an in-depth description of daily life within a multiethnic classroom. The conversations with the teachers lasted approximately 45 minutes and permitted the proposal of different themes, including the issue of knowledge of Italian by foreign students and the perception of the professional services of an intercultural mediator. The teachers' freedom of expression prevailed at all times, which sometimes led to more flexible discourses. The duration of the interview depended on the desire of each teacher to express their own opinions on the subjects in question. Many teachers used the interview almost as a way of venting and to report dysfunctions, which, in their opinion, Italian schools and, more precisely, Sicilian schools, suffer from. Others, on the other hand, seemed almost reluctant to establish a dialogue when replying to the various questions asked. All interviews were anonymous and conducted at different times, some during school hours, but mostly during the afternoon hours dedicated to the coordination of teaching teams. From the point of view of spatial location, interviews were conducted within the Istituto. All of them were recorded on a tablet electronic device with the express consent of the interviewees.

Although this paper is presented in English, the research team has carried out the field work in Italian, which is the mother tongue of the informant teachers and of a member of the research team. Consequently, the original text has been translated into English by specialized personnel.

\subsection{Data Analysis}

The interviews were transcribed in a comprehensive manner in text files resulting in twelve data collections. These data collections were analyzed for direct categorization according to the scheme shown in Table 2. For a more organized and intuitive management of the fragments, they were transferred to an Excel table with rows that itemized the teachers interviewed and columns depicting three principal categories, thus regrouping smaller segments into the three larger categories [56,57].

Table 2. Description of aims, objectives and segments (codes) (Own compilation).

\begin{tabular}{ccc}
\hline \multicolumn{1}{c}{ Aims } & Categories & Segments \\
\hline $\begin{array}{c}\text { Analyze teachers' perceptions, } \\
\text { attitudes and ideas about the } \\
\begin{array}{c}\text { impact of ignorance of Italian as } \\
\text { L2 by immigrant students. }\end{array}\end{array}$ & $\begin{array}{c}\text { Italian as the L2 of the immigrant } \\
\text { student }\end{array}$ & $\begin{array}{c}\text { Text referring to knowledge of } \\
\text { Italian as L2(L2I) }\end{array}$ \\
\hline $\begin{array}{c}\text { Understand how the impact of } \\
\text { intercultural mediators is } \\
\text { perceived in the internal } \\
\text { educational processes of schools. }\end{array}$ & The cultural mediator & $\begin{array}{c}\text { Text referring to role of the } \\
\text { cultural mediator (MDIC) }\end{array}$ \\
\hline
\end{tabular}

\section{Results}

\subsection{Italian as L2 of Immigrant Students}

Teachers consider the acquisition of Italian by foreign students as a basic issue, far from the previous idea of prioritizing the recognition of the native language of these students. For these teachers, it is the key to integration, which is the means by which "they gain self-confidence and allow the school year to continue" (IDOCprim9, L2I). Their statements highlight the importance of the Italian literacy project, whose objective is to teach Italian as a second language to foreign students, as well as its weaknesses and shortcomings. The aim of the course is to teach reading and writing and thus provide students with the necessary linguistic tools in Italian to address the school experience in a positive and meaningful way, guaranteeing the possibility of a smooth approach to learning other disciplines. Their interest is very much focused on the urgency of learning Italian, and they do not express concern that the course, in terms of its curriculum, is structured according to the ages or levels of the foreign 
students undertaking it. At the end of each learning unit, students are given a structured form in order to assess their achievement of the objectives related to the unit studied. This provides an opportunity to evaluate whether to continue on the planned study path or make adjustments, depending on the needs that may have arisen (IDOC4prim, L2I). The structure and aims developed by this literacy project confront us with a reality based on the practical thinking of teachers which may differ from what is usually recommended. The empirical evidence of our research shows that teachers do not enter into axiological debates about different interpretations of interculturalism, but rather want functional tools that facilitate daily life, they want a literacy project in the host language, in this case, Italian.

Unfortunately, although these types of projects are very useful for promoting linguistic recovery, for teachers they are not enough, and in their opinion, there are too few hours dedicated to the work of knowledge and consolidation of the Italian language aimed at foreign students. As Professor IDOC9prim affirms, surely through a linguistic literacy project, foreign students could simplify the process of insertion and integration within the school environment, thus favoring a more constructive approach to the class experience. This could be one of several measures that the school can take to avoid the marginalization of the student who does not speak Italian:

During the course of year, we might, if it is appropriate, talk to the principal and see if we can organize a reinforcement project in the afternoon to fill any gaps that they may have. My hope is that once the child has discovered reading, their plans, depending on their abilities, can improve and thus reach the same level of achievement as others in the school. Last year, I carried out a language literacy project with some colleagues for a small group of foreign children (IDOC9prim, L2I).

No plans are made, in fact, a linguistic recovery project has been carried out. But what is the purpose of a project that includes 20 hours of language learning and that helps these children recover language deficiencies? This is because the school has no money. It would also be useful for the school to create a network of ... how do you call it ... relationships with other schools, to understand if these children are included in the social fabric, but imagine ... an unthinkable idea ... coming back ... emmm ... yes ... going back to your initial question, I can say that the school has done very little for the inclusion of foreign students, but unfortunately there is no other option, there are no resources (IDOC8prim, L2I).

What was of repeated concern for the teachers in our study is that students should learn the Italian language as soon as possible. They believe that an improvement in the learning of the Italian language is very important for these students, and they consider the courses that some could classify as being assimilationist [58] in nature and that are aimed at foreign students to be useful and necessary tools. As can be seen in the words of Professor IDOC1prim, who realized that the manner in which they learned the Italian language had allowed the students to gain more confidence in themselves and in their own abilities, which in turn allowed them to face the school year with greater awareness and security:

Last year, for example, as I said, I did this course, the Italian language project L2. In summary, it was for foreign children and it was successful. I said to myself, 'here are the children'. There was a Nigerian girl, who at first had trouble, but later she was able to overcome her difficulties, though not one hundred percent, it always was for a limited time, however, she managed to gain self-confidence which allowed her to continue the school year. I see that she and her little brother are both more excited (IDOC1prim, L2I).

\subsection{The Role of Cultural Mediator}

The other important question that we asked teachers to analyze is their point of view with regard to the role of the cultural mediator. What we found was, just as with the issue of learning Italian, their point of view is very practical and functional. They see the mediator as making a professional contribution, as a facilitating resource, a delimited instrument that is responsible for additional actions 
that make teaching easier. In essence, the student must learn Italian and there must be professional mediators to act in a complementary manner and facilitate the teaching work. It is based on institutional demand but not part of systemic inter-professionalism. It is perceived as a basic tool that the teacher can use to help foreign students be successful at school.

I know that certain schools use a cultural mediator; in fact, I had the intention of doing so. However, since I had very little left in the secretariat budget, they told me that I had to make this request for a very short time [ ... ] -for the cultural mediator. It would be for this year for the Russian child because we encountered great difficulties (IDOC3prim, MDIC).

At first, the mediator could certainly feel comfortable to communicate with the student because at the beginning I tried ... , but the student could not understand, that is, we could not understand each other, this was probably at the beginning because I was communicating in the ... my language and I didn't know whether or not they understood me. So, from this point of view, yes, but we did it [ ... ]. We had no help from anyone (IDOC7prim, MDIC).

And I think that the only thing that could have been done was to have a cultural mediator, not only because of the language issue, but also because of the habits of these children to understand a little about family habits, lifestyle, and culture because it is ... emmm ... yes, they are children who adapt, are completely separated from their modus vivendi and inserted into a culture that is completely different from theirs (IDOC6prim, MDIC).

The teachers at the Istituto emphasized that they need to be able to rely on the collaboration of a cultural mediator, a role considered to be one of the measures that can be used to improve the reception and integration of foreign students, fostering the possibility of creating a dialogue and a way of communicating with the students themselves as well as among their peer group.

My main obstacle is the inability to communicate. I can use gestures with a child, but it is very limiting, I can communicate about $20 \%$ but no more, so the school should support me ... it should eliminate the obstacles, I should provide a cultural mediator, someone that could make it possible for me to communicate with the child. I must insist that this happen. My role, in this regard and up to this point, is to create a cozy atmosphere, a tranquil and very hospitable climate, I must try to insist that all obstacles are removed (IDOC2prim, MDIC).

In order to avoid the difficulties caused by the inability to interpret the behavioral and linguistic codes of new students, teachers demand, from the school institution where they offer their valuable service, the support of a cultural linguistic mediator to aid them in their complex work as pedagogical educators.

In short, we do not have specific data that can help us, we try to do everything possible to accommodate them as best we can with our own efforts and with whatever we have available. It would certainly be appropriate given the arrival of all these ..., of all these foreign families if there was the presence of a cultural mediator (IDOC10prim, MDIC).

We have mentioned it to the director several times, especially last year with the arrival of a Romanian girl. There were no few difficulties, we asked a colleague during the hours of co-presence, although those hours are always used for supply. But it is missing, this role is missing and I would consider it very useful [ . . . ] because these children almost always arrive overnight, so there is never enough time to prepare them (IDOC13prim, MDIC).

The mediator has never been ... emm ... as far as I know ... I don't know who is reponsible for their presence ... emmm ... surely our request ... but they never talked about it ... (IDOC8prim, MDIC). 
Teachers almost feel like scapegoats in this situation which, in and of itself, is very difficult to manage. However, it is made even more difficult when teachers are deprived of those tools with which each educational institution must be equipped, especially in light of users who are now more diverse and need more attention. Given the above, it is understandable that they do not assume all the burden of responsibilities of the school. However, it has been confirmed that what makes the situation more difficult to handle in the field of interculturalism is the perpetual lack of resources, certainly not the lack of desire on the part of teachers who carry out their work conscientiously and with due seriousness.

\section{Conclusions and Discussion}

In order for teachers to feel that they can successfully carry out the intercultural project, it is necessary to eliminate from the mind any idea that the foreign child, as a student, is a problem for the class and to involve the whole class group, a constant and repeated factor stated in various studies and contexts [43,59-61]. However, our empirical data emphasizes that teachers have the capacity to face problems with real and identifiable resources which can be used for the benefit of foreign students learning the host language, as well as to incorporate personnel specialized in mediation, moving away from more theorizing positions that usually transfer those responsibilities indefinitely without analyzing the real functional capacities of the school's actions. The results of our research distance themselves from those of other works in that may make value judgements about the teaching skills of education professionals from axiological positions $[22,23,60]$ and which have concluded that the system is undermined by the incapacity of Italian teachers and foreign students to understand each other due to their use of different communication channels. Thus, our evidence points to the learning of the host language as one of the instruments that is most necessary to promote inclusive action. The premise is that language plays a key role and is an instrument to be used for inclusion as it allows the individual to understand a new reality and be understood by others. In order to promote the true inclusion of migrants in the fabric of society of the adopted country, it is important to provide migrants with the necessary instruments for inclusion in the host society [62].

Notwithstanding the above, our evidence, as well as the research of others [46,47] leads us to conclude that the role of cultural mediator could effectively and efficiently assist teachers in their difficult task as well as aid foreign students as the mediator could understand their needs more easily. The use of a cultural mediator would mitigate the difficulties of establishing any form of dialogue between individuals who share the same space or environment, in this case, school children, with the final result of accelerating the insertion of foreign students into the classroom.

With regard to the issue of intercultural mediation, it would be desirable to create a collaborative network based on different types of exchanges between the various educational, political, and social institutions present in the region, whose contribution would be invaluable to achieve the insertion of young foreigners into the social fabric $[63,64]$. Unfortunately, this type of collaboration does not as yet exist or, in any case, is still considered insufficient and scarcely corresponds to the requests made by the school. There is little interaction between these institutions, whose functions, different but fundamental in several aspects, contribute to balancing the social and educational system.

Given the obstacles teachers face in the process of the integration of foreign students, the simplest form is often chosen, that is, to absorb social and cultural minorities into the dominant social and cultural system. The desired reality seems to indicate that a kind of assimilationism will be generated [58]. As has been stated in comprehensive reviews [65], young foreigners would shed most of what belongs to them in order to resemble their Sicilian peers. This could include their ways of doing things, their habits, or even their native language which eventually could run the risk of being forgotten.

This is the risk that occurs when schools lack structures capable of supporting it or the failure to collaborate to create a creative school environment. In these circumstances, the process of insertion will be based solely on the real abilities of teachers.

Teachers demonstrate their good intentions by keeping abreast of intercultural issues in order to adequately address the process of integrating foreign immigrant students, but their desire is focused on 
practical support mechanisms, both with regard to learning aids, the teaching of the host language as well as to the specialized help of cultural mediators. However, teachers perceive both of these support mechanisms to be insufficient or inadequate.

As teachers understand that they do not have easy access to the support of a cultural mediator [42], an instrument which they consider to be indispensable for fostering communication between all parties, they try to fulfill this role independently for themselves with the final goal being assimilation.

The convergence of multicultural and multiethnic situations can be translated into an opportunity or challenge for the enrichment and evolvement of a coexistence based on cooperation, exchange, and the productive acceptance of diversity as values and opportunities for democratic growth. The goal of intercultural education is the recognition and improvement of differences. In addition, schools must focus on individual identity and the different ways of belonging, where the acquisition of the host language and professional help of mediators are positive elements for an authentic fusion of values and ways of life among all the contact groups.

Finally, it should be noted that, like all research that seeks to delve into and understand the experiences of people going through complex situations, in this case, the interaction and perceived difficulties of linguistic integration of foreign students and the accompanying professional assistance offered by the school there are inherent limitations when it comes to generalizing, which we have reflected on in the conclusions and discussion section of this paper, reiterating important ideas that reaffirm the divergence that is usually observed between teachers and researchers of educational problems.

Author Contributions: Conceptualization, M.d.M.F.-M.; formal analysis, A.L.-d.l.R.; investigation, T.A.C.; supervision, J.J.C.-M.; validation, J.J.C.-M.; writing—original draft, M.d.M.F.-M.; review and editing, J.J.C.-M. and M.d.M.F.-M.

Funding: This research received no external funding.

Conflicts of Interest: The authors declare no conflict of interest.

\section{References}

1. Dennison, J.; Geddes, A.; Goodwin, M. Why Immigration Has the Potential to Upend the Italian Election. lse European Politics and Policy (Europp) Blog. 2018. Available online: http://eprints.lse.ac.uk/88403/1/ europpblog-2018-01-17-why-immigration-has-the-potential-to-upend-the.pdf (accessed on 18 August 2019).

2. United Nations High Commissioner for Refugees (UNHCR). Refugee and Migrant Arrivals to Europe-January to September 2019. 2019. Available online: http://data2.unhcr.org/en/documents/details/72161 (accessed on 6 November 2019).

3. Crawley, H.; McMahon, S.; Jones, K.; Duvell, F.; Sigona, N. Destination Europe? Understanding the Dynamics and Drivers of Mediterranean migration in 2015. Coventry: Centre for Trust, Peace and Social Relations, Coventry University. 2016, p. 83. Available online: http://pure.coventry.ac.uk/ws/portalfiles/portal/11554075/ MEDMIG_final_report_destination_europe.pdf (accessed on 6 November 2019).

4. Essomba, M.A. Politicas de escolarizacion del alumnado de origen extranjero en el estado español hoy. Anàlisis y propuestas. Rev. Electrònica Interuniv. Form. Profr. 2014, 17, 13-27. [CrossRef]

5. Rago, A. Confini Identitari. La Scuola Pugliese e Immigrazione. In Una Scuola Plurale, la Presenza Degli Alunni Stranieri in Puglia; di Vietro, R., Rago, A., Eds.; Ufficio Scolastico Regionale: Bari, Italy, 2009; pp. 31-63.

6. Biasutti, M.; Concina, E.; Frate, S. Working in the classroom with migrant and refugee students: The practices and needs of Italian primary and middle school teachers. Pedagog. Cult. Soc. 2019. [CrossRef]

7. Ministero della Pubblica Istruzione. Circolare Ministeriale; Ministero della Pubblica Istruzione: Rome, Italy, 1990; n. 205/1990.

8. Ministero della Pubblica Istruzione. Circolare Ministeriale; Ministero della Pubblica Istruzione: Rome, Italy, 1994; n. 73/1994.

9. Fiorucci, M. Accesso al sapere e diritto alla formazione come presupposti della democrazia. Pedagogia Oggi 1/2013 semestrale SIPED 2013, 1, 160-170. 
10. Urso, O. The politicization of immigration in Italy. Who frames the issue, when and how. Ital. Political Sci. Rev. Riv. Ital. Sci. Politica 2018, 48, 365-381. [CrossRef]

11. Santagati, M. Interculturalism, education and society: Education policies for immigrant students in Italy. Aust. N. Z. J. Eur. Stud. 2016, 8, 6-20.

12. Portera, A. Intercultural and multicultural education: Epistemological and semantic aspects. In Intercultural and Multicultural Education; Grant, C.A., Portera, A., Eds.; Routledge: London, UK, 2010; pp. 26-44.

13. Allemann-Ghionda, C. From intercultural education to the inclusion of diversity. Theories and Policies in Europe. In The Routledge International Companion to Multicultural Education; Banks, A., Ed.; Routledge: New York, NY, USA, 2009; pp. 134-145.

14. Arroyo González, M.J. La educación intercultural: Un camino hacia la inclusión educativa. Rev. Educ. Inclusiva 2017, 6, 144-159.

15. Hidalgo Hernández, V. Cultura, Multiculturalidad, Interculturalidad Y Transculturalidad: Evolución De Un Término. 2017, pp. 1-12. Available online: http://pedagogia.fcep.urv.cat/revistaut/revistes/juny05/article04. pdf (accessed on 7 November 2019).

16. Mostafazadeh, E.; Keshtiaray, N.; Ghulizadeh, A. Analysis of multi-cultural education concept in order to explain its components. J. Educ. Pract. 2015, 6, 1-12.

17. Kastoryano, R. Multiculturalism and interculturalism: Redefining nationhood and solidarity. Comp. Migr. Stud. 2018, 6, 17. [CrossRef]

18. Fernández-Castillo, A.F. Integración Educativa de Alumnado de Origen Inmigrante: Análisis Psicopedagógico. Rev. Iberoam. Educ. 2010, 51,1-12. Available online: http://dialnet.unirioja.es/servlet/ articulo? codigo=3112843 (accessed on 18 August 2019).

19. Dervin, F. Towards post-intercultural teacher education: Analysing 'extreme'intercultural dialogue to reconstruct interculturality. Eur. J. Teach. Educ. 2015, 38, 71-86. [CrossRef]

20. Leiva Olivencia, J.J. La Escuela Intercultural hoy: Reflexiones y perspectivas pedagógicas/Intercultural Education today: Pedagogical reflections and perspectives. Rev. Complut. Educ. 2017, 28, 29. [CrossRef]

21. Ambrosini, M.; Molina, S. Seconde Generazioni: Un'introduzione al Futuro Dell'immigrazione in Italia; Fondazione Giovanni Agnelli: Turin, Italy, 2004.

22. Catarci, M. L'orientamento interculturale nella scuola italiana tra modello "integrato" e "separato". Pedagogia Oggi n. 1/2010 semestrale SIPED 2010, 1, 129-144.

23. Dusi, P.; Steinbach, M. Voices of children and parents from elsewhere: A glance at integration in Italian primary schools. Int. J. Incl. Educ. 2016, 20, 816-827. [CrossRef]

24. Maalouf, A. A Rewarding Challenge: How the Multiplicity of Languages Could Strengthen Europe, Proposals from the Group of Intellectuals for Intercultural Dialogue; European Commission: Brussels, Belgium, 2008; Available online: http://eur-lex.europa.eu/legal-content/EN/TXT/PDF/?uri=CELEX:52008DC0566\&from=EN (accessed on 19 August 2019).

25. Vega Gil, L.; Hernández Beltrán, J.C. Los institutos universitarios de formación de profesores de Francia y la educación intercultural. Universidad de Salamanca. Facultad de Educación. Salamanca, Spain. Rev. Educ. 2012, 357, 305-326.

26. Fernández-Castillo, A. Estrategias de aprendizaje y adquisición de una segunda lengua. ReiDoCrea 2015, 4, 391-404. Available online: https://digibug.ugr.es/handle/10481/39335 (accessed on 26 July 2019).

27. Fernández Martínez, M.M.; Hernández Garre, C.M.; Luque de la Rosa, A.; Gutiérrez Cáceres, R.; Carrión Martínez, J.J. La superdiversidad, realidad incontestable: La co-inclusión reto ineludible para educadores y trabajadores sociales. In Proceedings of the 6th International Congress of Educational Sciences and Development, Setubal, Portugal, 21-23 June 2018; Asociación Española de Psicología Conductual (AEPC): Granada, Spain, 2018.

28. Gómez-Hurtado, I.; González-Falcón, I.; Coronel, J.M. Perceptions of secondary school principals on management of cultural diversity in Spain. The challenge of educational leadership. Educ. Manag. Adm. Leadersh. 2018, 46, 441-456. [CrossRef]

29. Geldof, D.; Schrooten, M.; Withaeckx, S. Transmigration: The rise of flexible migration strategies as part of superdiversity. Policy Politics 2017, 45, 567-584. [CrossRef]

30. Díez Gutiérrez, E.J. La práctica educativa intercultural en Secundaria. Rev. Educ. 2014, 363, 12-34. [CrossRef]

31. Ibarraran, A.; Lasagabaster, D.; Sierra, J.M. Multilingualism and language attitudes: Local versus immigrant students' perceptions. Lang. Aware 2008, 17, 326-341. [CrossRef] 
32. Sansó, C.; Navarro, J.L.; Huguet, Á. The evolution of language acquisition in immigrant students in Catalonia: The role of the home language. Electron. J. Res. Educ. Psychol. 2015, 13, 409-430.

33. Moreno-Manso, J.M.; Godoy-Merino, M.J.; Suárez-Muñoz, Á.; García-Baamonde, M.E. Communicative competence and the facilitating and perturbing factors in the socialisation of immigrant students. Child. Youth Serv. Rev. 2013, 35, 865-870. [CrossRef]

34. Cummins, J. Inclusion and Language Learning: Pedagogical Principles for Integrating Students from Marginalized Groups in the Mainstream Classroom. In Inklusion Im Englischunterricht; Bongartz, C., Rohde, A., Eds.; Peter Lang Edition: Frankfurt, Germany, 2015; pp. 95-116.

35. Susi, F. I Bisogni Formativi e Culturali Degli Immigrati Stranieri. La Ricerca-Azione Come Metodologia Educativa; Franco Angeli: Milan, Italy, 1991.

36. Susi, F. Come si è Ristretto il Mondo: L'educazione Interculturale in Italia e in Europa: Teorie, Esperienze e Strumenti; Armando Editore: Rome, Italy, 2008.

37. Fernández-Hawrylak, M.; Heras-Sevilla, D. Familias transnacionales, familias inmigrantes: Reflexiones sobre su inclusión en la escuela. Rev. Sociol. Educ. RASE 2019, 12, 24-39. [CrossRef]

38. Biasutti, M.; Concina, E.; Frate, S. Social Sustainability and Professional Development: Assessing a Training Course on Intercultural Education for In-Service Teachers. Sustainability 2019, 11, 1238. [CrossRef]

39. Martín-Mendoza, P. Inmigración, escuela e interculturalidad. Estado de la cuestión en Andalucía. ReiDoCrea 2018, 7, 395-403.

40. Gropas, R.; Triandafyllidou, A. Greek Education Policy and the Challenge of Migration: An 'Intercultural' View of Assimilation. Race Ethn. Educ. 2011, 14, 399-419. [CrossRef]

41. Kiel, E.; Syring, M.; Weiss, S. How Can Intercultural School Development Succeed? The Perspective of Teachers and Teacher Educators. Pedagog. Cult. Soc. 2017, 25, 243-261. [CrossRef]

42. Catarci, M. Intercultural Mediation as a strategy to facilitate relations between the School and Immigrant Families. Rev. Electron. Interuniv. Form. Prof. 2016, 19, 127-140. [CrossRef]

43. Leiva Olivencia, J.J. Abriendo Caminos de Interculturalidad e Inclusión en la Escuela; Dykinson: Madrid, Spain, 2016.

44. Ortiz Cobo, M.O.; Bianco, R. Mediación intercultural en el ámbito escolar: Entre la solidificación de la "semiprofesionalidad" y el futuro incierto. In Comprender el Presente, Imaginar el Futuro: Nuevas y Viejas Brechas Sociales; Martinez Paricio, J., Moreno Carrillo, J.M., Eds.; CORISCO Edizione: Messina, Italy, 2018; pp. 284-296.

45. Hernández Padros, M.; Allah, M.C.H. Escuela, inmigración y la figura del educador social. RES Rev. Educ. Soc. 2012, 16, 1-21. Available online: http://www.eduso.net/res (accessed on 22 July 2018).

46. Marques, J.C.; Vieira, A.; Vieira, R. Migration and Integration Processes in Portugal: The Role of Intercultural Mediation. Journal of Siberian Federal University. Humanit. Soc. Sci. 2019, 2, 187-205.

47. Sani, S. The role of intercultural mediation in the integration of foreign students. Procedia Soc. Behav. Sci. 2015, 191, 2582-2584. [CrossRef]

48. Smolyaninova, O.G.; Popova, J.V. Specific Issues of Training Intercultural Mediators for Education in Europe and Russia. Journal of Siberian Federal University. Humanit. Soc. Sci. 2019, 2, 247-260.

49. Stake, R.E. Investigación Con Estudio de Casos; Ediciones Morata: Madrid, Spain, 2007.

50. Albert Gómez, M.J. La Investigación Educativa: Claves Teóricas; McGraw-Hill: Madrid, Spain, 2009.

51. Goetz, J.P.; Lecompte, M.D. Etnografia y Diseño Cualitativo en Investigaciòn Educativa; Ediciones Morata: Madrid, Spain, 2011.

52. Flick, U. Introducción a la Investigación Cualitativa; Ediciones Morata: Madrid, Spain, 2012.

53. McMillan, J.H.; Schumacher, S. La Investigaciòn Educativa; Pearson: Madrid, Spain, 2009.

54. Verástegui Martinez, M. La feminización de la enseñanza en España:¿un objeto de estudio obsoleto? Indice Rev. Estad. Soc. 2019, 73, 28-31.

55. Hernández Sampieri, R.; Mendoza-Torres, C.P. Metodología de la Investigación: Las Rutas Cuantitativa, Cualitativa y Mixta; McGraw Hill: México City, México, 2018.

56. Rodríguez Gómez, G.; Gil Flores, J.; García Jiménez, E. Metodología de la Investigación Cualitativa; Aljibe: Málaga, Spain, 1999.

57. Fernández Sierra, J. El análisis de los datos cualitativos. In Conferencia Magistral en el Máster Universitario en Políticas y Prácticas de Innovación Educativa Para la Sociedad del Conocimiento, Almería; Universidad de Almería: Almeria, Spain, 2010. 
58. Marrone, J.V. Cultural Assimilation as a Human Capital Formation Process: Theory and Empirical Evidence; The University of Chicago: Chicago, IL, USA, 2017.

59. Bhatnagar, J. Educating Immigrants; Routledge: London, UK, 2017.

60. Santagati, M. Researching Integration in Multiethnic Italian Schools. A Sociological Review on Educational Inequalities. Ital. J. Sociol. Educ. 2015, 7, 294-334. [CrossRef]

61. Strzemecka, S. School integration in the eyes of migrant children. Based on the Polish migration to Norway. Przeglad Socjologiczny 2015, 64, 81-101.

62. Carloni, G.; Sisti, F. Language learning and inclusion in Italy. Lang. Learn. High. Educ. 2019, 9, 97-115. [CrossRef]

63. Medvedeva, M.; Portes, A. Immigrant bilingualism in Spain: An asset or a liability? Int. Migr. Rev. 2017, 51, 632-666. [CrossRef] [PubMed]

64. Gallo, A.E. Assessing the Efficacy of Integration Strategies for Immigrant Communities: A Case Study of the United States and France. Master's Theses, City College of New York, New York, NY, USA, December 2015. Available online: http://academicworks.cuny.edu/cc_etds_theses/583 (accessed on 22 August 2019).

65. Azzolini, D.; Mantovani, D.; Santagati, M. Italy: Four Emerging Traditions in Immigrant Education Studies. In The Palgrave Handbook of Race and Ethnic Inequalities in Education; Stevens, P.A.J., Dworkin, A.G., Eds.; Palgrave Macmillan: Gurgaon, India, 2019; pp. 695-745.

(C) 2019 by the authors. Licensee MDPI, Basel, Switzerland. This article is an open access article distributed under the terms and conditions of the Creative Commons Attribution (CC BY) license (http://creativecommons.org/licenses/by/4.0/). 